\title{
Na selva das imagens: Algumas contribuições para uma teoria da imagem na esfera das ciências da comunicação
}

Malena Segura Contrera Norval Baitello Junior Mackenzie/UNIP - PUC/SP 


\section{Resumo}

O número de autores e obras que se dedicam à compreensão dos fenômenos relacionados com a visualidade e sua exacerbação nas últimas décadas do século XX tem crescido, e, consequentemente, vem se acirrando a polêmica em torno deste campo de saber. As contribuições da neurologia, da psicologia, das ciências sociais e das ciências da linguagem sobre o tema têm se mostrado imprescindíveis para uma maior compreensão dos significados e dos usos da imagem para o campo da comunicação. Alguns desses aportes são tratados aqui, notadamente aqueles que transitam pelas áreas da teoria da cultura em suas interfaces com as ciências da comunicação; dentre eles, autores como A. Damásio, B. Cyrulnik, E. Morin, D. Linke e H. Belting recebem atenção privilegiada por transporem as fronteiras da monodisciplinaridade, oferecendo perspectivas mais complexas e processuais para o estudo da imagem no campo da comunicação, fugindo das tipologizações classificatórias.

\section{Abstract}

The number of authors and works dedicated to the understanding of phenomena related to the visuality and its exacerbation in the last decades of the twentieth century has grown, and, consequently, the controversy around this field has been stirred. The contributions of neurology, psychology, social sciences and sciences of the language on the subject have proved essential for a larger understanding of the meanings and uses of image in the field of communication. Some of these contributions are treated here, notably those who transit through the areas of the theory of culture in its interfaces with sciences of communication; amongst them, authors such as A. Damásio, B. Cyrulnik, E. Morin, D. Linke and H. Belting receive privileged attention for transposing the borders of monodisciplinarity, offering more complex and procedural perspectives for the study of image in the field of communication, avoiding classificatory uses of tipology. 


\section{Sobrevivência na selva da polissemia: sobre o conceito de imagem}

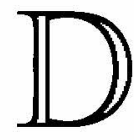

etlev Linke, em seu livro Arte e cérebro - A conquista do invisivel (2001:11-21), reitera o importante papel da luz para a história do homem. Mas, ao mesmo tempo lembra que o homem não é um ser de luz (Lichtwesen); apenas uma pequena parcela de seus pensamentos seria transparente. Afirma que após a Psicanálise também a pesquisa neurológica vem mostrando que "os luminosos cristais de gelo da consciência estão ocultos, em mais de nove décimos, no mar dos processos impenetráveis". Assim, seríamos semi-zumbis (Halbzombies), cuja consciência obedece a um autômato praticamente desconhecido. E "as zonas frutíferas do espírito se situariam entre o mar das imagens e o deserto da solidão".

Vivendo, no entanto em meio ao dilúvio das imagens luminosas da sociedade midiática, pouco podemos saber sobre elas mesmas, por excesso de proximidade e por falta de obscuridade. Assim, ganha terreno uma discussão menos simplista sobre este "mar", como constituição de uma teoria da imagem.

Iniciando pelo mais palpável e palatável dentro de um conceito em sua origem pouco palpável e ainda menos palatável, ${ }^{1}$ as chamadas ciências duras nos oferecem algumas indispensáveis "imagens conceituais" sobre as imagens. Buscando chão firme para um conceito

1. A etimologia revela que a palavra latina 'imago' possui uma forte vinculação com os retratos de pessoas mortas. Poderiamos especular que a obscura origem da palavra latina, com muitas possiveis raízes indo-européias, tenha nascido mesmo das representações dos mortos. Cf. Baitello (2000). 
muitas vezes fluido. Apenas dentro do campo da Neurologia já poderíamos enumerar listas de autores, ${ }^{2}$ mas talvez nenhum deles tenha se dedicado tão centralmente ao tema como o neurologista Antonio Damásio:

"Imagem designa um padrão mental em qualquer modalidade sensorial, como, por exemplo, uma imagem sonora, uma imagem tátil, a imagem de um bem-estar. Essas imagens comunicam aspectos das características físicas do objeto e podem comunicar também a reação de gostar ou não gostar que podemos ter em relação ao um objeto, os planos referentes a ele que podemos ter ou a rede de relações desse objeto em meio a outros objetos." (A. Damásio: 2000: 24-25) ${ }^{3}$

2. Oliver Sacks, Alexander Romanovitch Lurija, Detlev Linke poderiam oferecer apenas alguns dos exemplos muito interessantes. Os dois primeiros relatam com grande acuidade anamneses de individuos que padeceram de diferentes tipos de neuropatologias das imagens (imagens acústicas, visuais ou proprioceptivas). O último, igualmente neurologista, mas também filósofo, professor de filosofia e comunicólogo, constrói uma instigante reflexão sobre a imagem artística e seus fundamentos neurológicos (sobretudo em obras como Kunst und Gehirn. Die Eroberung des Unsichtbaren - Arte e cérebro. A conquista do invisivel ). Ainda mais profundo, na đireção de uma arqui-etologia ou de uma eto-arqueologia da imagem, oferecem-nos os trabalhos de investigação sobre a capacidade pictórica de chimpanzés e gorilas relatados por Desmond Morris (1968). em seu Biology of art (Der malende Affe, München: dtv).

3. Para uma compreensão cognitiva de imagem, citamos António Damásio, em um fragmento que ressalta a importância das imagens na construção do pensamento humano: "Refiro-me ao termo imagens como padrões mentais com uma estrutura construida com os sinais provenientes de cada uma das modalidades sensoriais - visual, auditiva, olfativa, gustatória e sômato-sensitiva. A modalidade sômato-sensitiva (a palavra provém do grego sôma, que significa 'corpo') inclui várias formas de percepção: tato, temperatura, dor, e muscular, visceral e vestibular. A palavra imagem não se refere apenas a imagem 'visual', e também não há nada de estático nas imagens... As imagens de todas as modalidades 'retratam' processos e entidades de todos os tipos, concretos e abstratos. As imagens também 'retratam' as propriedades fisicas das entidades e, às vezes imprecisamente, às vezes não, as relações espaciais e temporais entre entidades, bem como as ações destas. Em suma, o processo que chegamos a conhecer como mente quando imagens mentais se tornam nossas, como resultado da consciência, é um fluxo contínuo de imagens, e muitas delas se revelam logicamente inter-relacionadas. O fluxo avança no 
Damásio, em outro momento de $O$ mistério da consciência deixa claro que toma o conceito de "imagem" como sinônimo do de "representação", reafirmando o que sabemos sobre as representações ao dizer que a representação, longe de reproduzir o objeto percebido pelos sentidos, é uma construção cognitiva:

"Ademais, seja qual for o grau de fidelidade (ao objeto percebido), os padrões neurais e as imagens mentais correspondentes são criações do cérebro tanto quanto produtos da realidade externa que levou à sua criação."

(A. Damásio: 2000: 405)

Neste sentido há duas questões que nos parecem pertinentes aos estudos da imagem no âmbito das Ciências da Comunicação (e da Teoria da Mídia):

a) em primeiro lugar, o fluxo de mão dupla existente entre a motivação interna, de natureza psíquica e a captação externa que se articula na criação das imagens com as quais pensamos. Tal fluxo de mão dupla inaugura a discussão sobre as teorias do imaginário, por um lado, e as teorias da recepção, por outro. Também a questão das imagens psíquicas e a questão das imagens oníricas caberiam ser discutidas neste âmbito da Teoria da Imagem;

b) em segundo lugar, as conseqüências (sócio-ecológicas e ecopsicológicas) do predomínio avassalador dos sistemas comunicativos sensório-visuais em detrimento das outras modalidades perceptivas. Os sistemas perceptivos de tipo tátil, olfativo, gustativo, até mesmo a comunicação de tipo auditivo, mas especialmente aqueles que Damásio chama de sômatosensitivos, ${ }^{4}$ necessariamente são afetados pela hipertrofia da

tempo, rápido ou lento, ordenadamente ou aos trambolhões, e às vezes segue não uma, mas várias seqüências. Às vezes as seqüências são concorrentes, outras vezes convergentes e divergentes, ou ainda sobrepostas. Pensamento é uma palavra aceitável para denotar esse fluxo de imagens." (A. Damásio: 2000: 402-403)

4. "Até mesmo os sentimentos que constituem o pano de fundo de cada instante mental são imagens, no sentido exposto acima: imagens sômato-sensitivas, ou seja, que sinalizam principalmente aspectos do estado do corpo." (A. Damásio: 2000: 403). 
visualidade. Isto nos conduz às reflexões críticas cada vez mais freqüentes sobre a era da exacerbação da visualidade, do simulacro e da iconofagia. ${ }^{5}$

Tais questões nos levam a considerar a tipologia proposta pelo teórico da mídia e historiador da imagem Hans Belting, que postula a distinção entre imagens endógenas e imagens exógenas. Tal tipologia nos possibilitará operar com hipóteses e cenários bastante interessantes, abrindo perspectivas investigativas para uma possivel teoria da imagem que não se restrinja às puras classificações formais, de tipo semiótico ou de qualquer outro tipo, mas que considere ecossistemas comunicativos históricos em sua complexidade (desde já etológica, artística, sócio-antropológica, psicológica, epistemológica, histórica e comunicativa).

Se buscarmos, por exemplo, pela história da imagem necessariamente temos de lembrar da importante questão que E. Morin já levantou sobre as primeiras formas de representação e da utilização das imagens nos ritos preparatórios de caça do homem primitivo. Baseando-se na noção de duplo, ele diz sobre a função mágica das imagens que:

“Desde então, a imagem não é só uma simples imagem, mas contém a presença do duplo do ser representado e permite, por seu intermédio, agir sobre esse ser; é esta ação que é propriamente mágica: rito de evocação pela imagem, rito de invocação à imagem, rito de possessão sobre a imagem (enfeitiçamento)". (E. Morin: 1988: 98-99)

Assim, segundo Morin, a função inicial da imagem é representativa, é tornar presente o ausente, ou atingi-lo de algum modo em sua própria materialidade, e essa função é exercida desde o início em uma prática essencialmente mágica. Tal função, bastante conhecida e já exaustivamente estudada, não constitui, no entanto,

5. Como, por exemplo, trabalham os autores: P. Virillio, J. Baudrillard, D. Kamper, N. Baitello Jr. e outros. 
uma característica apenas arcaica da imagem ou mesmo uma função apenas das imagens em âmbitos de culto. Ao contrário, sabe-se que esse potencial enfeitiçador da imagem é amplamente usado em nossos dias pela televisão, pelo cinema, pela internet, pela publicidade, pela moda. E isto lança uma luz, por exemplo, sobre os mecanismos de vinculação e seus efeitos psicológicos e cognitivos que constituem o recente fenômeno da teleparticipação e da teledependência, permitindo compreendê-los melhor. Assim os hard-users ${ }^{6}$ poderiam ser comparados a zumbis contemporâneos, enfeitiçados pelas imagens ao extremo, a ponto de perder a própria identidade, que se funde psicologicamente ao universo simbólico da mídia eletrônica.

E. Morin, ainda contribuindo enormemente para uma melhor compreensão do papel antropológico e comunicativo da imagem, analisa seu papel enquanto eidolon (in O Paradigma Perdido) que exerce um enorme poder de invasão, evocando no homem toda a carga projetiva de que sua afetividade é capaz. Os fenômenos comunicativos de massa exploraram e exploram (economicamente, ideologicamente) ao extremo esse poder de cristalização e potencialização simbólica da imagem na criação dos ídolos da cultura pop. Por isso, na publicidade, por exemplo, não se trata apenas de convencer de que o produto oferecido é desejável, mas sobretudo de reiterar à exaustão o poder da própria forma de oferecimento, da própria linguagem "enfeitiçadora" das imagens idólatras.

A partir de uma outra perspectiva, mas chegando a resultados análogos, o etólogo Boris Cyrulnik fala de um "ensorcellement du monde", enfeitiçamento do mundo, de um encantamento e de uma captura a partir das imagens (visuais, auditivas, olfativas, táteis):

"As imagens visuais e as imagens sonoras realizam grandes actuacões a fim de cativarem a atenção do outro. Assim que se pode sugerir uma imagem visual ou auditiva, muda-se de registro; cativa-se a atenção, desencadeando uma representação. 'A visão é a arte de ver coisas

6. Sobre esse fenômeno dos hard-ursers na comunicação, Leão Serva se refere, no livro Jornalismo e Desinformação. 
invisiveis' [ ], com a condição de saber evocar imagens. $A$ audição permite, também ela, ver coisas invisiveis, com a condição de saber articular as palavras que as fazem ver. Deste modo, a molécula move e comove, a pressão fisica capta tocando, ao passo que a gustação e o olfacto afloram a boca do cérebro do nariz. Estas estimulações sensoriais imobilizam por um breve instante, exactamente $o$ tempo de provocarem um movimento de atracção ou de fuga, de cheiro ou de mastigação. Este não é o caso das imagens visuais e auditivas que captam e põem na expectativa." (B. Cyrulnik: 1999: 97-98)

\section{Imagens endógenas e imagens exógenas: o imaginário e a ecologia da comunicação}

As imagens geradas pelo universo interior, que o alimentam e movimentam, trazidas à consciência e partilhadas pelos diferentes sistemas de tradução, constituem as chamadas imagens endógenas. Dentre elas sempre se destacaram como campo de atenção do homem aquelas produzidas involuntariamente pelo sono paradoxal (já presente nos animais superiores a partir da homeotermia), as imagens oníricas. Independentes da vontade e da consciência e voluntariosamente enigmáticas e cifradas, tais imagens sempre motivaram tentativas de sistemas interpretativos que buscam correspondências exteriores. Sua natureza de imagem interior inaugura por assim dizer uma maneira própria de codificação, com uma sintaxe própria, com um sistema semântico de peculiar complexidade e um repertório ou "vocabulário" indissociáveis da história e das histórias pessoais, ou seja, da vivência cultural do sonhador. ${ }^{7}$

7. Cabe também aqui lembrar a presença importantíssima do "sonho diurno" (Tagtraum), figura-chave da filosofia de Ernst Bloch, uma espécie de transição para a construção de cenários prospectivos e retrospectivos mais abstratos que conferem ao homem sua capacidade de abstração. Ou ainda a técnica terapêutica desenvolvida por C. G. Jung, a imaginação ativa, que ele mesmo descrevia como uma espécie de sonhar acordado auto-induzido. 
Já aquelas imagens criadas para transitar pelo universo exterior, sobre suportes materiais fixos ou móveis, constituiriam as chamadas imagens exógenas. Seu percurso histórico e seu papel social se confundem e se mesclam com a história humana de registrar suas imagens, desde as primeiras representações paleolíticas conhecidas, passando pela criação de figuras de culto, pelas transformações pictográficas que darão origem à escrita, pelos diversos sistemas de escrita e pelas recentes formas da imagem mediática. Indispensável relembrar aqui a importante passagem do valor de culto para o valor de exposição, assinalada por Walter Benjamin, demarcando a era da reprodutibilidade técnica como o início da proliferação das imagens exógenas.

Ambas, imagens endógenas e imagens exógenas, são evidentemente mediadoras de sentidos e enquanto as imagens exógenas veiculam esses sentidos em mensagens inter-pessoais, as endógenas são portadoras de mensagens intra-pessoais. A leitura dos sentidos que essas imagens carregam ocupou desde sempre a atenção dos agrupamentos sociais: até mesmo a leitura das imagens oníricas constituía tema central das sociedades arcaicas que entendiam que o sonho possuía caráter oracular e deveria portanto ser compartilhado com todo o grupo. Assim, havia menos dissociação entre o universo das imagens endógenas e exógenas, alimentando e garantindo os processos de simbolização. ${ }^{8}$

Esse movimento de mão dupla e sua homeostase é que se encontra afetado com a exacerbação das imagens exógenas, já que quanto mais aumenta o seu fluxo, mais somos solicitados (e vemos nossa atenção nisso concentrada) a um contínuo movimento de exteriorização. Na mesma proporção dedica-se tanto menos atenção às imagens endógenas. Estas, é claro, não se extinguem, mas tornamse cada vez mais inacessíveis, relegadas a um segundo e terceiro planos. Ao invés de cumprirem o papel de alimentar o âmbito externo, passam a espelhá-lo indiscriminada e acriticamente. O resultado é

8. Sobre a questão da crise das capacidades simbólicas e o literalismo, ver o artigo "Jornalismo e Midia - paranóia e crise das competências simbólicas", Revista Ghrebh no. 1, www.cisc.org.br/ghrebh. 
que o homem do séculos XX e XXI se vê continuamente solicitado a responder às imagens do mundo, mas não pode organizá-las no seu próprio mundo interior, caótico e subnutrido de vínculos internos, perdendo o contato com suas próprias histórias. ${ }^{9}$ Assim, o homem contemporâneo está cada vez mais saturado de imagens exógenas e subnutrido de imagens endógenas. Este seria um dos fenômenos que contribuem para o atual desequilíbrio na 'ecologia da comunicação'. ${ }^{10}$

\section{A imagem e sua função vinculadora}

A partir do momento da pré-história em que o homem desenvolve a representação a partir do surgimento da consciência (cf. E. Morin), inicialmente tomando-a como duplo do representado, passa imediatamente a utilizá-la para se aproximar desse ser por ela representado, ou a ele se referir, ou ainda a ele se relacionar por meio de processos simbólicos. A imagem inaugura então sua grande função, seu papel de vinculadora. Esse processo, que é a própria essência da representação e da criação da linguagem humana é, desde seu início, um processo semiótico, ou seja, de criação de imagens cognitivas portadoras de sentido para o homem imaginante.

E essa questão é significativa para nossa reflexão porque a imagem só vincula quando ela é portadora de sentido. As imagens sem sentido da iconofagia são um testemunho do desespero humano das sociedades modernas superpopulosas e isolacionistas ${ }^{11}$ pela criação de vínculos.

Nascida a partir da consciência, a imagem não se dissocia desta jamais, o que implica que o processo do que denominamos

9. Conforme J. Hillman, em Cidade e Alma e em Cem anos de psicologia e o mundo está cada vez pior.

10. Sobre o tema da Ecologia da Comunicação, referimo-nos ao conceito proposto por Vicente Romano, em um livro que se encontra em processo final de tradução e que em breve será lançado pela Ed. Annablume, de S. Paulo. Uma amostra de suas idéias a respeito podem ser encontradas em seus textos que se encontram no site www.cisc.org.br/biblioteca.

11. Sobre o fenômeno da superpopulação temos um belo texto de K. Lorenz, em seu livro Civilização e Pecado. 
consciência, e ao qual já nos referimos acima, é fundamental para organizar um sistema de significação pessoal a partir do qual as imagens exógenas possam ser percebidas e assimiladas num sistema complexo de significados. Quando a consciência está sub-alimentada pelas imagens endógenas, ou seja, quando não há vida simbólica interior, vida reflexiva, o sistema cognitivo pessoal acaba se colocando mais no papel de mero consumidor das imagens exógenas oferecidas pelo mercado do que como receptor e transformador dessas imagens, extraindo delas apenas os seus significados funcionais, e não os demais significados mais complexos que elas poderiam evocar. E no final as imagens exógenas restam ocas e inúteis, obtendo apenas resposta de padrões psíquicos autômatos e inconscientes como os padrões maníacos do consumo.

Quando eu comunico a imagem que tenho em minha mente (imagem endógena), imagem interna, esbarro na questão de que necessito de códigos, de suportes perceptíveis, de mídia para fazê-la chegar ao meu interlocutor/receptor, e ao fazer isso, é já a natureza desses elementos que está em questão e não mais apenas a natureza da imagem mental que se quer comunicar. A questão de perceber/ filtrar/organizar que se impõe à recepção das imagens exógenas (as publicitárias, por exemplo) faz com que, ao receber uma imagem, estejamos muito mais expostos às especificidades desses elementos (código, mídia) do que ao conteúdo endógeno da imagem que se queria comunicar. Ou seja, estamos mais expostos ao ritual de enfeitiçamento do que ao teor do feitiço propriamente dito, como dizíamos anteriormente.

Nesse sentido, a mídia (com seus códigos, suportes, etc.) impõe uma natureza, uma materialidade que já não é mais a da imagem endógena que o emissor imaginou, mas que é na verdade uma imagem de sua própria natureza midiática, uma imagem de si mesma (ou uma imagem auto-referente), traindo a natureza da imagem endógena motivadora do processo e rompendo o vínculo com as imagens endógenas, criando e alimentando um universo de superficialidades irrefletíveis, que apenas se dão a devorar.

Esse processo não acontece subitamente na história da imaginação humana, e alguns de seus degraus podem ser claramente 
percebidos, momentos de um processo que também poderíamos nos referir como sendo aquele através do qual vai se perdendo o contato com as percepções concretas e as imagens sômato-motoras, indispensáveis para a formação da consciência humana (o que implica também em autoconsciência).

Nas sociedades arcaicas a imagem busca a representação. A imagem que representa propõe-se a tornar presente o ausente. Nas sociedades modernas, temos a imagem que constitui o universo do simulacro proposto por J. Baudrillard, aqui a imagem já não se preocupa mais com o referencial concretamente experimentado, ela simplesmente simula a existência de um referencial concreto, mentindo a respeito de sua existência (o que na sociedade da velocidade e do consumo passa a já não mais importar).

Contemporaneamente, vivemos em sociedade iconofágicas, e o fenômeno que temos é ainda mais extremo: inventa-se a imagem sem sequer a mínima referência a nenhum fenômeno percebido, sem a necessidade sequer de mentir, de simular. ${ }^{12} \mathrm{O}$ que importa já não é nem mais a imagem simulada, é apenas o processo de mostragem, de explicitação, do consumo e do auto-consumo ${ }^{13}$ que se realiza por meio desse processo.

As experiências da percepção concreta (ou seja, as imagens que A. Damásio chama de sômato-motoras ou os processos cognitivos que F. Varella chama de enactivos) simplesmente não entram no jogo. É a era do homem que não é mais capaz de conjugar sua experiência perceptiva com sua vivência interior (a dissociação plena de uma era esquizofrênica), já que toda a forma de percepção e de vivência interior passa a ser submetida à era da vertiginosa produção de imagens funcionais que só se referem a si mesmas.

Dessa forma, põe-se a perder o poder maior das imagens percebidas (imagens exógenas) que reside justamente em acionar o repertório de significados que o receptor possui em sua memória cognitiva advindo de outras imagens que compõem esse repertório

12. Cf. Boorstin, Daniel (1961).

13. Sobre a questão do auto-consumo, referimo-nos ao apresentado no livro $O$ Método V, de E. Morin. 
imaginativo composto de uma gama de variedades sensoriais (imagens sômato-motoras, inclusive). Na contemporaneidade, por conta do exaustivo uso comercial das imagens visuais, essas imagens visuais percebidas evocam, por parte do receptor, apenas o desencadeamento cognitivo de mais imagens visuais do mesmo tipo, gerando um quadro muito próximo dos labirintos de espelhos nos quais a proliferação infinita das imagens apenas conduz ao nada.

\section{Bibliografia}

BAITELLO, N., "As imagens que nos devoram: Antropofagia e Iconofagia", 2000, www.cisc.org.br/biblioteca.

BAUDRILLARD, J. A ilusão vital. R. de Janeiro: Civilização Brasileira, 2001.

. A troca impossivel. R. de Janeiro: Nova Fronteira, 2002.

BELTING, Hans. Likeness and presence: a history of image before the era of art. Chicago: Chicago P., 1994.

L'image et son public au Moyen Age. Paris: Monfort, 1998a.

Image et culte. Paris: Cerf., 1998b.

BELTING, Hans \& KAMPER, D. Der zweite Blick. Bildgeschichte und Bildreflexion, München: W.Fink, 2000.

BELTING, Hans. Bild-Anthropologie. München: W.Fink, 2000.

Il culto delle imagini. Storia dell'icona dall'età imperiale al tardo Medioevo. [...]: Nis Carocci Editore, 2001.

BOORSTIN, Daniel (1961) The image or What happened to the American dream. N. York: Atheneum.

CONTRERA, M. S. (2002) Mídia e pânico: saturação da informação, violência e crise cultural na midia. S. Paulo: Annablume. (2002) "Jornalismo e mídia - paranóia e crise das competências simbólicas", Revista Virtual Ghrebh- no. 1, www.cisc.org.br/ghrebh.

DAMÁSIO, A. O mistério da consciência. S. Paulo: Cia. das Letras, 2000. 
DURAND, G. A imaginação simbólica. Lisboa: Ed. 70, 1995.

Estruturas antropológicas do imaginário. S. Paulo: Martins Fontes, 1997.

. Campos do imaginário. Inst. Piaget, Lisboa, 1998.

HILlMAN, J. Cidade e alma. S. Paulo: Nobel, 1993.

JUNG, C. G. A natureza da psique. Petrópolis: Vozes, 1986. . Vida simbólica. Ed. Vozes, Petrópolis, 2000.

LINKE, Detlev. Kunst und Gehirn. Die Eroberung des Unsichtbaren. Reinbeck: Rowohlt, 2001.

MORIN, E. (1988) O homem e a morte. Lisboa: Publ. EuropaAmérica.

O paradigma perdido. Lisboa: Publ. Europa-América, 1988. . O método 5. P. Alegre: Sulina, 2002.

MORRIS, Desmond (1968) Der malende Affe (Biology of art). München: dtv. 